\title{
Synthesis and evaluation of arylfuryl-bis(indolyl)methanes as selective chromogenic and fluorogenic ratiometric receptors for mercury ion in aqueous solution
}

\author{
Rosa M. F. Batista, Susana P. G. Costa, Regina M. P. Silva, Nuno E. M. Lima, M. \\ Manuela M. Raposo* \\ Centre of Chemistry, University of Minho, Campus of Gualtar, 4710-057 Braga, \\ Portugal \\ *Corresponding author Tel: + 351253 604381; Fax: + 351253604382 \\ email:mfox@quimica.uminho.pt
}

\begin{abstract}
A series of arylfuryl-bis(indolyl)methane derivatives 2 were prepared in good yields by electrophilic substitution of indole with furyl aldehydes through a simple and mild hydrogensulfate-catalyzed reaction and studied as chemosensors for transition metal cations by performing spectrophotometric and spectrofluorimetric titrations. Selective recognition of $\mathrm{Hg}^{2+}$ was achieved in organic aqueous mixture $\left(\mathrm{CH}_{3} \mathrm{CN} / \mathrm{H}_{2} \mathrm{O}\right.$, $7: 3$ ) for the various receptors, with an easily detectable colour change from colourless to purple and also through a fluorescence quenching, making these compounds suitable for dual chromo- and ratiometric fluorogenic sensing of $\mathrm{Hg}^{2+}$. The binding stoichiometry between the receptors and $\mathrm{Hg}^{2+}$ was found to be $1: 1$. The binding process was also followed by ${ }^{1} \mathrm{H}$ NMR titrations which corroborated the previous findings.
\end{abstract}

Keywords: Bis(indolyl)methanes; arylfuran; ratiometric fluorogenic chemosensors; $\mathrm{Hg}^{2+}$; direct visual detection; aqueous solution.

\section{Introduction}

Chemosensors and chemodosimeters that can monitor heavy metal ions with high sensitivity and selectivity are especially important owing to the great concern with environment and health. Among transition and heavy metals, mercury, from a variety of natural and anthropogenic sources and widely distributed in water, soil and air, is 
considered to be one of the most toxic because both ionic and elemental mercury can be converted by bacteria in the environment to methyl mercury, which subsequently bioaccumulates through the food chain. Mercury causes serious neurotoxic, genotoxic, and immunotoxic effects and thus poses severe risk for human beings and other organisms. Therefore, selective and sensitive detection of $\mathrm{Hg}^{2+}$ has been an important topic of investigation [1]. Presently, several methods such as atomic absorption/emission spectroscopy, inductively coupled plasma-mass spectrometry, voltammetry, etc. can be used in order to detect $\mathrm{Hg}^{2+}$. However, all these methods have drawbacks such as expensive instrumentation, only measure the total metal ion content and are not suitable for on-site assays [2]. Therefore, an easy and straightforward method that detects and quantifies $\mathrm{Hg}^{2+}$ is advantageous for instantaneous monitoring of environmental, biological, and industrial samples which occur in aqueous solution. Consequently, much attention has been paid to developing low-cost and easily-prepared colorimetric and/or fluorimetric mercury sensors that work in the aqueous medium [1ab,d-f,h-m]. $\mathrm{Hg}^{2+}$ is usually associated with a fluorescence quenching by different mechanisms, so a ratiometric approach for its detection (simultaneous monitoring of fluorescence intensity at two different wavelengths) would be preferable, since it minimizes interferences from other species present in the media [1b,i,1].

Although indoles are predominant in natural compounds and widely applied in the synthesis of pharmaceutical products, they were only recently recognized as useful building blocks for the assembly of synthetic anionic receptors [3]. Among the several indole-based systems, triaryl- and triheteroarylmethanes have found wide range applications in different areas of chemistry, due to their structure (presence of a pyrrolic $\mathrm{NH}$ group) and photophysical properties, such as chemical sensors [3-5] and as precursors in the synthesis of heterocyclic systems for molecular electronics [6] Therefore, there is a great deal of interest in the synthesis of this class of compounds and while several indole-based receptors have been developed for the selective sensing and detection of anions [3-5] only a few examples can be found in the literature for cation receptors bearing an indole group [7].

Recently, the synthesis and evaluation of new bis-indolylmethenes containing thienyl and bithienyl moieties has been reported by us in order to evaluate the effect of the length of the $\pi$-conjugated bridge and also the electronic nature of these heterocycles on the sensory properties of these chromophores [8]. Keeping in mind our interests in the synthesis of colorimetric/fluorimetric chemosensors for selective detection of 
cations and anions, we proceeded to synthesize new non-oxidized bis-indolylmethane derivatives containing functionalized arylfuryl moieties and evaluate their chemosensory ability. The main difference resides in the replacement of the $\pi$ conjugated bi(thiophene) spacer by an arylfuryl system (instead of the more commonly used aryl group), allowing a more sensitive fluorimetric detection due to the higher fluorescent character of the heteroaromatic furan when compared to thiophene [9]. On the other hand, the different electronic nature of the substituents at the arylfuryl group was used to tune the photophysical properties of the resulting compounds. These nonconjugated bis-indolylmethane derivatives with an $\mathrm{sp}^{3}$ carbon at meso position may even promote more significant color changes when compared with the previous examples, probably because the interaction with cations can occur through a variation in carbon hybridization with concomitant modulation of the internal charge transfer (ICT) state.

\section{Experimental}

\subsection{Synthesis general}

Reaction progress was monitored by thin layer chromatography $(0.25 \mathrm{~mm}$ thick precoated silica plates: Merck Fertigplatten Kieselgel 60 F254), while purification was effected by silica gel column chromatography (Merck Kieselgel 60; 230-400 mesh). NMR spectra were obtained on a Varian Unity Plus Spectrometer at an operating frequency of $300 \mathrm{MHz}$ for ${ }^{1} \mathrm{H}$ and $75.4 \mathrm{MHz}$ for ${ }^{13} \mathrm{C}$ or a Bruker Avance III 400 at an operating frequency of $400 \mathrm{MHz}$ for ${ }^{1} \mathrm{H}$ and $100.6 \mathrm{MHz}$ for ${ }^{13} \mathrm{C}$ using the solvent peak as internal reference. The solvents are indicated in parenthesis before the chemical shift values ( $\delta$ relative to TMS and given in ppm). Mps were determined on a Gallenkamp apparatus. Infrared spectra were recorded on a BOMEM MB 104 spectrophotometer. Mass spectrometry analyses were performed at the "C.A.C.T.I. -Unidad de Espectrometria de Masas" at the University of Vigo, Spain. Fluorescence spectra were collected using a FluoroMax-4 spectrofluorometer. UV-visible absorption spectra (200 - $700 \mathrm{~nm}$ ) were obtained using a Shimadzu UV/2501PC spectrophotometer. Luminescence quantum yields were measured using quinine sulphate in $0.5 \mathrm{M}$ sulphuric acid solution as standard $\left(\phi_{\mathrm{F}}=0.54\right)[10]$. All commercially available reagents were used as received. 


\subsection{Synthesis of 5-(4'-methoxyphenyl)furan-2-carbaldehyde (1b)}

5-Bromofuran-2-carbaldehyde $(1.5 \mathrm{mmol})$ was coupled with 4methoxyphenylboronic acid $(1.9 \mathrm{mmol})$ in a mixture of DME $(15 \mathrm{~mL})$, aqueous $2 \mathrm{M}$ $\mathrm{Na}_{2} \mathrm{CO}_{3}(1 \mathrm{~mL})$ and $\mathrm{Pd}\left(\mathrm{PPh}_{3}\right)_{4}(6 \mathrm{~mol} \%)$ at $80{ }^{\circ} \mathrm{C}$ under argon. The reaction was monitored by TLC and after cooling, the mixture was filtered. Ethyl acetate and a saturated solution of $\mathrm{NaCl}$ were added and the phases were separated. The organic phase was washed with water $(3 \times 50 \mathrm{~mL})$ and with a solution of $\mathrm{NaOH}(10 \%)(1 \times 50$ $\mathrm{mL})$. The organic phase obtained was dried $\left(\mathrm{MgSO}_{4}\right)$, filtered and the solvent removed to give a crude mixture. The crude residue was submitted to silica gel column chromatography using mixtures of hexane and chloroform of increasing polarity. The fractions containing the purified product were collected and evaporated under vacuum to afford product $\mathbf{1 b}$ as orange oil (82\%). IR (liquid film): $v=1667,1590,1500,1213$, 1176, 1112, 1066, 1020, 965, 830, $767 \mathrm{~cm}^{-1} .{ }^{1} \mathrm{H} \mathrm{NMR}\left(\mathrm{CDCl}_{3}\right): \delta=3.86\left(\mathrm{~s}, 3 \mathrm{H}, \mathrm{OCH}_{3}\right)$, $6.96(\mathrm{dd}, 2 \mathrm{H}, J=9.0$ and $2.1 \mathrm{~Hz}, \mathrm{H} 3$ ' and H5'), 7.29 (d, 1H, $J=3.9 \mathrm{~Hz}, \mathrm{H} 4), 7.62$ (dd, $2 \mathrm{H}, J=9.0$ and $2.1 \mathrm{~Hz}, \mathrm{H} 2{ }^{\prime}$ and $\mathrm{H} 6$ '), 7.71 (d, 1H, $J=3.9 \mathrm{~Hz}, \mathrm{H} 3$ ), 9.86 (s, 1H, CHO) ppm.

\subsection{General procedure for the synthesis of bis(indolyl)methanes $\mathbf{2 a - d}$}

$\mathrm{KHSO}_{4}(1.20 \mathrm{mmol})$ was added to a mixture of indole $(2.40 \mathrm{mmol})$ and the corresponding aldehyde 1a-d $(1.20 \mathrm{mmol})$ in dry methanol $(10 \mathrm{~mL})$, and the reaction was stirred at room temperature for $7 \mathrm{~h}$. Then water $(10 \mathrm{~mL})$ was added to quench the reaction, and the aqueous phase was extracted with $\mathrm{CHCl}_{3}(3 \times 20 \mathrm{~mL})$. The organic phase was dried with anhydrous $\mathrm{MgSO}_{4}$, and the crude compounds 2 were purified by recrystallization from $\mathrm{CHCl}_{3}$.

\subsubsection{3-((1H-Indol-3-yl)(5'-phenylfuran-2'-yl)methyl)-1H-indole (2a).}

Pink solid (50 \%). Mp: 192.0-193.0 ${ }^{\circ} \mathrm{C}$. IR (Nujol) $v=3412,3055,2955,2925,1610$, 1594, 1544, 1419, 1336, 1214, 1203, 1090, 1018, 789, 763, $745 \mathrm{~cm}^{-1}$. ${ }^{1} \mathrm{H}$ NMR (acetone- $\left.d_{6}\right) \delta=6.09(\mathrm{~s}, 1 \mathrm{H}, \mathrm{CH}), 6.23(\mathrm{~d}, 1 \mathrm{H}, J=3.3 \mathrm{~Hz}, \mathrm{H} 3$ '), 6.79 (d, 1H, $J=3.3$ Hz, H4'), 6.98 (dt, 2H, $J=7.6$ and $1.4 \mathrm{~Hz}, 2 \mathrm{x} \mathrm{H} 5$ ), 7.11 (dt, 2H, $J=7.6$ and $1.4 \mathrm{~Hz}, 2 \mathrm{x}$ H6), 7.17 (d, 2H, J=2.1 Hz, 2 x H2), 7.24 (m, 1H, H4'’), 7.38-7.42 (m, 2H, H3', and H5' '), 7.44 (dt, 2H, $J=7.5$ and $1.4 \mathrm{~Hz}, 2$ x H7), 7.59 (d, 2H, $J=7.5 \mathrm{~Hz}, 2 \times \mathrm{H} 4), 7.68$ 
(d, 2H, $J=8.3 \mathrm{~Hz}, \mathrm{H} 2$ ' ' and H6' '), 10.11 (s, 2H, $2 \times \mathrm{NH}) \cdot{ }^{13} \mathrm{C}$ NMR (acetone- $\left.d_{6}\right) \delta=$ $35.2(\mathrm{CH}), 106.7$ (C4’), 109.2 (C3'), 112.2 (2 x C7), 117.2 (2 x C3), 119.4 (2 x C5), 120.2 (2 x C4), 122.1 (2 x C6), 124.0 (C2'” and C6" ), 124.2 (2 x C2), 127.6 (C4"'), 127.8 (2 x C3a), 129.5 (C3'” and C5'), 132.2 (C1'’), 137.9 (2 x C7a), 153.0 (C5'), 158.8 (C2'). MS (EI) m/z (\%): $388\left(\mathrm{M}^{+}, 42\right), 283$ (100), 273 (23), 168 (20), 117 (21), 77 (13). HRMS: (EI) $m / z(\%)$ for $\mathrm{C}_{27} \mathrm{H}_{20} \mathrm{~N}_{2} \mathrm{O}$; calcd 388.1576; found 388.1577.

\subsubsection{3-((1H-Indol-3-yl)(5'-(4' '-methoxyphenyl)furan-2'-yl)methyl)-1H-indole (2b).}

Purple solid (40 \%). Mp: 115.0-116.0 ${ }^{\circ} \mathrm{C}$. IR (Nujol) $v=3411,2920,1616,1598,1547$, 1498, 1420, 1295, 1249, 1176, 1094, 1021, 967, 832, 782, $743 \mathrm{~cm}^{-1}$. ${ }^{1} \mathrm{H}$ NMR (acetone$\left.d_{6}\right) \delta=3.82\left(\mathrm{~s}, 3 \mathrm{H}, \mathrm{OCH}_{3}\right), 6.06(\mathrm{~s}, 1 \mathrm{H}, \mathrm{CH}), 6.18(\mathrm{~d}, 1 \mathrm{H}, J=3.3 \mathrm{~Hz}, \mathrm{H} 3$ '), $6.61(\mathrm{~d}, 1 \mathrm{H}$, $J=3.3 \mathrm{~Hz}, \mathrm{H} 4$ '), 6.94-7.00 (m, 4H, H3', ${ }^{\mathrm{H} 5}$ '' and $2 \mathrm{x} \mathrm{H5),} 7.10$ (dt, 2H, J=7.8 Hz, 2 x H6), 7.15 (d, 2H, $J=2.4 \mathrm{~Hz}, 2$ x H2), 7.42 (d, 2H, $J=7.8 \mathrm{~Hz}, 2$ x H7), 7.57-7.63 (m, $4 \mathrm{H}, \mathrm{H} 2$ ', $\mathrm{H} 6$ "' and $2 \times \mathrm{H} 4), 10.10\left(\mathrm{~s}, 2 \mathrm{H}, 2 \times \mathrm{N} H\right.$ ). ${ }^{13} \mathrm{C}$ NMR (acetone- $\left.d_{6}\right) \delta=35.2$ $(\mathrm{CH}), 55.5\left(\mathrm{OCH}_{3}\right), 104.9\left(\mathrm{C}^{\prime}\right.$ '), $109.0\left(\mathrm{C}^{\prime}\right.$ '), 112.2 (2 x C7), 114.9 (C3'” and C5'), 117.4 ( 2 x C3), 119.4 ( 2 x C5), 120.2 (2 x C4), 122.0 (2 x C6), 124.2 (2 x C2), 125.2 (C1'), 125.5 (C2', and C6'), 127.8 (2 x C3a), 137.9 (2 x C7a), 153.2 (C5'), 157.9

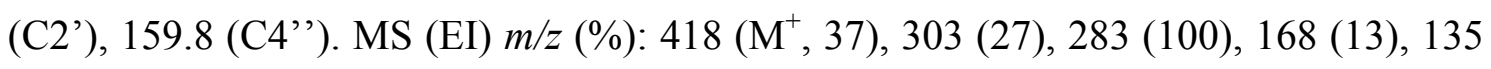
(18), 117 (21). HRMS: (EI) $m / z$ (\%) for $\mathrm{C}_{28} \mathrm{H}_{22} \mathrm{~N}_{2} \mathrm{O}_{2}$; calcd 418.1681; found 418.1682.

\subsubsection{3-((5'-(4' '-Bromophenyl)furan-2'-yl)(1H-indol-3-yl)methyl)-1H-indole (2c).}

Pale pink solid (54 \%). Mp: $116.0-117.0{ }^{\circ} \mathrm{C}$. IR (Nujol) $v=3409$, 2919, 1538, 1477 , $1418,1338,1242,1205,1094,1073,1008,967,826,783,743 \mathrm{~cm}^{-1} .{ }^{1} \mathrm{H}$ NMR (acetone$\left.d_{6}\right) \delta=6.08(\mathrm{~s}, 1 \mathrm{H}, \mathrm{CH}), 6.25$ (d, 1H, $J=3.2 \mathrm{~Hz}, \mathrm{H} 3$ '), 6.85 (d, 1H, J=3.2 Hz, H4'), 6.97 (t, 2H, $J=7.2 \mathrm{~Hz}, 2$ x H5), 7.10 (t, 2H, $J=7.2 \mathrm{~Hz}, 2$ x H6), 7.16 (d, 2H, $J=1.6$ Hz, 2 x H2), 7.42 (d, 2H, J=8.4 Hz, 2 x H7), 7.54-7.63 (m, 6H, H2' ', H3', , H5' ', H6', and $2 \times \mathrm{H} 4), 10.10(\mathrm{~s}, 2 \mathrm{H}, 2 \times \mathrm{NH}) \cdot{ }^{13} \mathrm{C} \mathrm{NMR}\left(\mathrm{CDCl}_{3}\right) \delta=34.3(\mathrm{CH}), 106.4\left(\mathrm{C}^{\prime}\right)$, 109.0 (C3'), 111.1 (2 x C7), 116.9 (2 x C3), 119.4 (2 x C5), 119.7 (2 x C4), 120.4 (C4'”), 121.9 (2 x C6), 123.1 (2 x C2), 124.9 (C2'” and C6"'), 126.7 (2 x C3a), 130.1 (C1',), 131.6 ( C3' 'and C5''), 136.5 (2 x C7a), 151.5 (C5), 157.3 (C2'). MS (ESI) $\mathrm{m} / \mathrm{z}$ (\%): $467\left(\mathrm{M}+{ }^{81} \mathrm{Br}, 35\right), 465\left(\mathrm{M}+{ }^{79} \mathrm{Br}, 35\right), 431$ (28), 367 (28), 345 (66), 289 (14), 231 (49), 227 (100), 187 (30), 159 (16). HRMS: (ESI) $m / z$ (\%) for $\mathrm{C}_{27} \mathrm{H}_{18}{ }^{81} \mathrm{BrN}_{2} \mathrm{O}$ calcd 467.05779; found 467.05753. $\mathrm{C}_{27} \mathrm{H}_{18}{ }^{79} \mathrm{BrN}_{2} \mathrm{O}$; calcd 465.05970; found 465.05900. 
2.3.4. 3-((1H-Indol-3-yl)(5'-(4''-nitrophenyl)furan-2'-yl)methyl)-1H-indole (2d).

Yellow solid (65\%). Mp: 119.0-120.0 ${ }^{\circ} \mathrm{C}$. IR (Nujol) $v=3409,2925,1602,1536,1507$, 1335, 1109, 1096, 1057, 1022, 968, 852, 783, 742, $722 \mathrm{~cm}^{-1} .{ }^{1} \mathrm{H}$ NMR (acetone- $\left.d_{6}\right) \delta=$ $6.14(\mathrm{~s}, 1 \mathrm{H}, \mathrm{CH}), 6.36\left(\mathrm{~d}, 1 \mathrm{H}, J=4.4 \mathrm{~Hz}, \mathrm{H} 3{ }^{\prime}\right), 6.99(\mathrm{dt}, 2 \mathrm{H}, J=7.2$ and $0.8 \mathrm{~Hz}, 2 \mathrm{x}$ H5), 7.09-7.15 (m, 3H, 2 x H6 and H4'), 7.19 (d, 2H, $J=2.4$ Hz, 2 x H2), 7.44 (d, 2H, $J$ $=8.5 \mathrm{~Hz}, 2 \times \mathrm{H} 7), 7.20$ (d, 2H, $J=8.5 \mathrm{~Hz}, 2 \times \mathrm{H} 4), 7.91(\mathrm{dd}, 2 \mathrm{H}, J=7.2$ and $2.0 \mathrm{~Hz}$, H2' and H6'), 8.25 (dd, 2H, $J=7.2$ and $2.0 \mathrm{~Hz}, \mathrm{H} 3$ ' 'and H5' ), 10.15 (s, 2H, 2 x NH).

${ }^{13} \mathrm{C}$ NMR (acetone- $\left.d_{6}\right) \delta=35.3(C \mathrm{H}), 110.3\left(\mathrm{C}^{\prime}\right.$ '), $111.5\left(\mathrm{C}^{\prime}\right.$ '), 112.3 (2 x C7), 116.7 (2 x C3), 119.5 (2 x C5), 120.1 ( 2 x C4), 122.2 (2 x C6), 124.3 (2 x C2), 124.4 (C2'” and C6"), 125.1 (C3"'and C5'), 127.7 (2 x C3a), 137.7 (C1'”), 137.9 (2 x C7a), 146.9 (C4'’), 151.1 (C5'), 161.5 (C2'). MS (EI) m/z (\%): 456 (M+, 19), 432 (58), 359 (25), 313 (42), 245 (100), 218 (72), 179 (23). HRMS: (EI) $m / z$ (\%) for $\mathrm{C}_{27} \mathrm{H}_{19} \mathrm{~N}_{3} \mathrm{NaO}_{3}$; calcd 456.13186; found 456.13041 .

\subsection{Spectrophotometric and spectrofluorimetric titrations of compounds $\mathbf{2 a - d}$}

Solutions of bis-(indolyl)methane derivatives 2 a-d $\left(c a .1 .0 \times 10^{-5}\right.$ to $1.0 \times 10^{-6}$ $\mathrm{M})$ and of the cations under study (ca. $1.0 \times 10^{-1}$ to $1.0 \times 10^{-3} \mathrm{M}$ ) were prepared in $\mathrm{MeCN} / \mathrm{H}_{2} \mathrm{O}$ (7:3) (in the form of hexahidratated tetrafluorborate salts for $\mathrm{Cu}^{2+}, \mathrm{Co}^{2+}$, $\mathrm{Ni}^{2+}, \mathrm{Pd}^{2+}$, and perchlorate salts for $\mathrm{Cd}^{2+}, \mathrm{Ca}^{2+}, \mathrm{Na}^{+}, \mathrm{Cr}^{3+}, \mathrm{Zn}^{2+}, \mathrm{Hg}^{2+}, \mathrm{Fe}^{2+}$ and $\mathrm{Fe}^{3+}$ ). Titration of the compounds was performed by the sequential addition of a metal cation to the bis-(indolyl)methane derivative solution, in a $10 \mathrm{~mm}$ path length quartz cuvette and emission spectra were measured by excitation at the wavelength of maximum absorption for each compound, indicated in Table 1. The binding stoichiometry of the bis-(indolyl)methane derivatives with the metal cations was determined by using Job's plots, by varying the molar fraction of the cation while maintaining constant the total bis-(indolyl)methane derivative and metal cation concentration. The association constants were obtained from Hyperquad Software.

\section{Results and discussion}

\subsection{Synthesis and characterization}

A new series of arylfuryl-bis(indolyl)methanes 2 was synthesized with substituents such as alkoxy, bromo or nitro, in order to evaluate the influence of the electron 
donating or withdrawing strength of the substituent groups on the optical and sensing properties of the receptors. These compounds were obtained in moderate to good yields (40-65\%) by condensation of indole with several formyl precursors 1 with substituents of different electronic nature in dry methanol in the presence of potassium hydrogensulfate [11] (Scheme 1). Formyl-arylfuran precursors 1a and 1c-d were commercially available and 5-(4'-methoxyphenyl)furan-2-carbaldehyde 1b [12] was synthesized by us through Suzuki cross-coupling reaction [13].

\section{$<$ Scheme 1 $>$}

These new systems constituted by aryl-furan $\pi$-conjugated bridges displayed an increased intramolecular charge transfer due to the high eletronegativity of the oxygen at the heteroaromatic ring. As a consequence, the acidity of the indolyl NH was increased, with a bathochromic shift in absorption and emission bands and quite pronounced color changes. In compound $\mathbf{2} \mathbf{b}$ the electron donor methoxy group induced a certain decrease in the acidity of the NH proton $(\delta=10.10 \mathrm{ppm})$ when compared to the arylfuryl-bis(indolyl)methane functionalized with a nitro group (compound $\mathbf{2 d}, \delta=$ $10.15 \mathrm{ppm})$. A dramatic bathochromic shift from $289 \mathrm{~nm}$ to $370 \mathrm{~nm}$ was observed for compound $\mathbf{2 d}$, when compared with compound $\mathbf{2 b}$, being a direct consequence of the electronic nature of the substituent at the arylfuran moiety. The high fluorescence of the furan ring also gave these new systems the advantage of using a more sensitive technique to detect metal cations. The relative fluorescence quantum yields were determined using a $10^{-6} \mathrm{M}$ solution of quinine sulfate in $0.5 \mathrm{M} \mathrm{H}_{2} \mathrm{SO}_{4}$ as standard $\left(\phi_{\mathrm{F}}=0.54\right)$ [10]. The absorption and emission spectra of arylfuryl-bis(indolyl)methanes 2 were measured in $\mathrm{MeCN} / \mathrm{H}_{2} \mathrm{O}$ (7:3) solution $\left(10^{-6}\right.$ to $10^{-5} \mathrm{M}$ solution) (Table 1). Arylfuryl-bis(indolyl)methanes $\mathbf{2}$ exhibited different fluorescence quantum yields according to the functionalization at the furan ring: higher $\phi_{\mathrm{F}}$ for the hydrogen and methoxy groups ( 0.21 and 0.58 , respectively for compounds $\mathbf{2 a - b}$ ), and low fluorescence in the case of compounds $\mathbf{2 c - d}$ with bromine and nitro groups $\left(\phi_{\mathrm{F}} 0.01\right.$ and 0.001, respectively). Considering these photophysical properties, derivatives 2a-b would be the more interesting candidates as chemosensors due to the higher fluorescence quantum yields, important for maximization of the response in the analysis of very dilute samples. 
$<$ Figure 1 $>$

$<$ Table 1 $>$

\subsection{Spectrophotometric/spectrofluorimetric titrations and chemosensing studies of $2 a$ -} d with metallic cations

Compounds 2a-d were evaluated as chemosensors in the presence of several metal cations $\left(\mathrm{Cu}^{2+}, \mathrm{Co}^{2+}, \mathrm{Ni}^{2+}, \mathrm{Pd}^{2+}, \mathrm{Cd}^{2+}, \mathrm{Ca}^{2+}, \mathrm{Cr}^{3+}, \mathrm{Zn}^{2+}, \mathrm{Hg}^{2+}, \mathrm{Fe}^{2+}\right.$ and $\left.\mathrm{Fe}^{3+}\right)$ in $\mathrm{MeCN} / \mathrm{H}_{2} \mathrm{O}(7: 3)$ solutions. The hexahydratated tetrafluorborate salts of $\mathrm{Cu}^{2+}, \mathrm{Co}^{2+}$, $\mathrm{Ni}^{2+}$ and $\mathrm{Pd}^{2+}$ and perchlorate salts of $\mathrm{Cd}^{2+}, \mathrm{Ca}^{2+}, \mathrm{Cr}^{3+}, \mathrm{Zn}^{2+}, \mathrm{Hg}^{2+}, \mathrm{Fe}^{2+}$ and $\mathrm{Fe}^{3+}$ were added to solutions of $\mathbf{2 a - d}\left(10^{-4} \mathrm{M}\right)$, in order to evaluate their chemosensory ability. A preliminary study with 100 equiv of the cations revealed that compounds 2a-d responded selectively to the presence of $\mathrm{Hg}^{2+}$ with a distinct color change from colorless to purple (Figure 2).

$<$ Figure 2 $>$

Regarding the fluorimetric response, selectivity towards $\mathrm{Hg}^{2+}$ was also achieved with a clearly visible quenching in the fluorescence intensity, (Figure 3), that can be attributed to electron and/or energy transfer processes due to empty d shell of $\mathrm{Hg}^{2+}[7 \mathrm{c}]$.

\section{$<$ Figure 3 $>$}

Spectrophotometric titration of compounds $\mathbf{2 a - b}, \mathbf{d}$ in $\mathrm{MeCN} / \mathrm{H}_{2} \mathrm{O}(7: 3)\left(10^{-5}-10^{-}\right.$ $\left.{ }^{6} \mathrm{M}\right)$ with $\mathrm{Hg}^{2+}$ revealed a trend in the UV-vis spectra: the intensity of the longest wavelength absorption band (between 290-377 nm) decreased progressively upon addition of the metal cation, with the simultaneous growth of a new red-shifted absorption band located between 505-543 $\mathrm{nm}$. On the other hand, for compound 2c there was a very slight increase of the corresponding absorption band at $267 \mathrm{~nm}$ together with the appearance of a new band at $518 \mathrm{~nm}$ of low intensity (Figure 4). The number of necessary metal equivalents to achieve a plateau was between 30-40 equivalents for compounds $\mathbf{2} \mathbf{a}-\mathbf{c}$ and at about 100 equivalents for compound $\mathbf{2 d}$. 
In order to gain insight into the interaction mechanism between the cation and the receptors, similar titrations with $\mathrm{Hg}^{2+}$ were also conducted in $\mathrm{MeCN} / \mathrm{H}_{2} \mathrm{O}$ at different $\mathrm{pH}$ (2.05 and 7.05). In both cases there was no formation of the red-shifted band upon addition of the metal, revealing that no interaction took place due to the fact that the indolyl $\mathrm{NH}$ was protonated.

The association constants ( $\left.K_{\text {ass }}\right)$, the detection (LOD) and quantification (LOQ) limits were also obtained from the results of the spectrophotometric titrations in $\mathrm{MeCN} / \mathrm{H}_{2} \mathrm{O}$ (7:3) (Table 2). The highest association constant was found for compound 2b bearing the electron donor methoxy group linked to the arylfuryl moiety.

\section{$<$ Table 2>}

The stoichiometry of the complexes was obtained by the changes in the colorimetric response of compounds $\mathbf{2 a - d}$ in the presence of varying concentrations of $\mathrm{Hg}^{2+}$ (Figure 5). The results indicated an empirical 1:1 ratio (L:M), which is also in agreement with the stoichiometry suggested from Hyperquad Software.

\section{$<$ Figure 5 $>$}

As for the spectrofluorimetric titrations in $\mathrm{MeCN} / \mathrm{H}_{2} \mathrm{O}$ (7:3), only compounds 2a-b were studied since the other compounds were not fluorescent. The response to the presence of $\mathrm{Hg}^{2+}$ was seen by a variation in the fluorescence intensity of the emission band (Figure 5), after excitation at the maximum wavelength of absorption of the ligand and of the complex between the metal and the ligand. The results are similar for both compounds, with a quenching of fluorescence being visible for the ligand emission band, whereas the opposite effect occurred with an increase of the fluorescence intensity for the complex emission band (Figure 6), illustrating the ratiometric response of receptors $\mathbf{2 a - b}$ to different $\mathrm{Hg}^{2+}$ concentrations. The number of necessary metal equivalents to achieve a plateau was at about 30 equivalents for compounds $\mathbf{2 a - b}$.

$<$ Figure 6> 
From the results of the spectrofluorimetric titrations in $\mathrm{MeCN} / \mathrm{H}_{2} \mathrm{O}$ (7:3) for compounds $\mathbf{2 a - b}$, it was possible to calculate association constants $\left(K_{\text {ass }}\right)$, the detection (LOD) and quantification (LOQ) limits, which are between 8 and 11 ppm (Table 3). Recently, several receptors have been reported for the detection and quantification of $\mathrm{Hg}^{2+}$ in organic and aqueous media, with limits of detection and quantification in the ppm-ppb range $[1 b, \mathrm{i}]$.

\section{$<$ Table 3>}

As can be seen by the LOD and LOQ data presented in Tables 2 and 3, the values obtained by spectrophotometric and spectrofluorimetric titrations are in agreement, especially for compound $\mathbf{2 b}$.

\section{3. ${ }^{1} \mathrm{H}$ NMR titrations}

The sensory behaviour observed by the spectrophotometric/spectrofluorimetric titrations was also confirmed by performing ${ }^{1} \mathrm{H}$ NMR titrations but due to the limited solubility of compounds 2 a-d in deuterated acetonitrile, the titrations were carried out with $\mathrm{Hg}^{2+}$ in acetone- $d_{6}$ at room temperature (representative example for compound $\mathbf{2 b}$ in figure 7 ).

\section{$<$ Figure 7 >}

The signal of the indolyl NH appearing at about $10 \mathrm{ppm}$ was further shifted downfield ( $\Delta \delta \sim 0.8 \mathrm{ppm}$ ) upon addition of up to 6 equivalents of $\mathrm{Hg}^{2+}$, thus suggesting that the interaction with the metal cation is occurring at this site. The chemical shifts of the remaining protons were unaffected by the metal interaction.

\section{Conclusions}

The selective determination of $\mathrm{Hg}^{2+}$ in $\mathrm{MeCN} / \mathrm{H}_{2} \mathrm{O}$ (7:3) solution among various transition metal cations was possible with novel arylfuryl-bis(indolyl)methane derivatives bearing different electron donor and acceptor substituents. All the compounds 2a-d exhibited a selective and significant colour change from colourless to purple, whereas a marked quenching of the fluorescence was additionally observed for 
compounds 2a-b, making these compounds suitable for dual chromo- and fluorimetric sensing of $\mathrm{Hg}^{2+}$ in aqueous mixtures. The binding stoichiometry between the receptors and $\mathrm{Hg}^{2+}$ was found to be $1: 1$, and the results obtained through UV-vis and ${ }^{1} \mathrm{H}$ NMR titrations were found to be in agreement, suggesting the formation of a complex between the metal and the ligand through interaction with the indolyl NH group.

\section{Acknowledgements}

Thanks are due to the Foundation for the Science and Technology (FCT, Portugal) for financial support to the NMR Portuguese network (PTNMR, Bruker Avance III 400Univ. Minho), FCT and FEDER (European Fund for Regional Development)COMPETE-QREN-EU for financial support to the Research Centre, CQ/UM [PEstC/QUI/UI0686/2011 (FCOMP-01-0124-FEDER-022716)] and the post-doctoral grant to R.M.F. Batista (SFRH/BPD/79333/2011).

\section{References and notes}

[1] (a) Liu Z, He W, Guo Z. Metal coordination in photoluminescent sensing. Chem. Soc. Rev. 2013;42:1568-1600;

(b) Kim HN, Ren WX, Kim JS, Yoon J. Fluorescent and colorimetric sensors for detection of lead, cadmium, and mercury ions. Chem. Soc. Rev. 2012;41:32103244 ;

(c) Kaur K, Saini R, Kumar A, Luxami V, Kaur N, Singh P, Kumara S. Chemodosimeters: an approach for detection and estimation of biologically and medically relevant metal ions, anions and thiols. Coord. Chem. Rev. 2012;256:1992-2028;

(d) Dutta M, Das D. Recent developments in fluorescent sensors for trace-level determination of toxic-metal ions. Trends Anal. Chem. 2012;32:113-132;

(e) Formica M, Fusi V, Giorgi L, Micheloni M. New fluorescent chemosensors for metal ions in solution. Coord. Chem. Rev. 2012;256:170-192;

(f) Kaur N, Kumar S. Colorimetric metal ion sensors. Tetrahedron 2011;67:92339264;

(g) Quang DT, Kim JS. Fluoro- and chromogenic chemodosimeters for heavy metal ion detection in solution and biospecimens. Chem. Rev. 2010;110:62806301 ; 
(h) Zhang JF, Kim JS. Small-molecule fluorescent chemosensors for $\mathrm{Hg}^{2+}$ ion. Anal. Sci. 2009;25:1271-1281;

(i) Nolan EM, Lippard SJ. Tools and tactics for the optical detection of mercuric ion. Chem. Rev. 2008;108:3443-3480;

(j) Callan JF, de Silva AP, Magri DC. Luminescent sensors and switches in the early 21 st century. Tetrahedron. 2005;61:8551-8588;

(k) Valeur B, Leray I. Design principles of fluorescent molecular sensors for cation recognition. Coord. Chem. Rev. 2000;205:3-40.

(1) Dereka B, Scechkarev D, Doroshenko AO. Facile ultrasensitive monitoring of mercury ions in water by fluorescent ratiometric detection. Cent. Eur. J. Chem. 2013;11:584-593 and references cited therein.

(m) Wang, H-F, wu S-P. Highly selective fluorescent sensors for mercury(II) ions and their applications in living cells imaging. Tetrahedron, 2013;69:1965;

[2] (a) Leermakers M, Baeyens W, Quevauviller P, Horvat M. Mercury in environmental samples: speciation, artifacts and validation. Trends Anal. Chem. 2005;24:383;

(b) Butler OT, Cook JM, Harrington CF, Hill, SJ, Rieuwerts J, Miles DL. Atomic spectrometry update. Environmental analysis J. Anal. At. Spectrom. 2006;21: 217; (c) Li Y, Chen C, Li B, Sun J, Wang J, Gao Y, Zhao Y, Chai Z. Elimination efficiency of different reagents for the memory effect of mercury using ICP-MS, J. Anal. At. Spectrom. 2006;21:94;

(d) Gao C, Huang X-J. Voltammetric determination of mercury(II). Trends in Analytical Chemistry 2013;51:1-12.

[3] (a) Gale PA. Synthetic indole, carbazole, biindole and indolecarbazole-based receptors: applications in anion complexation and sensing. Chem. Comm. 2008;4525-4540.

(b) Juwarker H, Suk J-m, Jeong K-S. in: Gale PA, Dehaen W (Eds.). Indoles and related heterocycles anion recognition in supramolecular chemistry. Springer Berlin/Heidelberg, 2010, Vol. 24, pp. 177-204;

(c) Wenzel M, Hiscock J R, Gale PA. Anion receptor chemistry: highlights from 2010. Chem. Soc. Rev. 2012;41:480-520.

[4] For some recent examples see: (a) Gu X, Liu C, Zhu Y-C, Zhu Y-Z. A boron-dipyrromethene-based fluorescent probe for colorimetric and ratiometric detection of sulfite. J. Agr. Food. Chem. 2011;59:11935-11939; 
(b) Li Q, Guo Y, Xu J, Shao SJ. Novel indole based colorimetric and "turn on" fluorescent sensors for biologically important fluoride anion sensing. J. Photochem. Photobiol. B. 2011;103:140-144;

(c) Lv YJ, Guo Y, Xu J, Shao SJ. Simple indole-based colorimetric sensors with electron-withdrawing chromophores: Tuning selectivity in anion sensing. J. Fluorine Chem. 2011;132:973-977;

(d) Wang L, He X, Guo Y, Xu J, Shao S. Tris(indolyl)methene molecule as an anion receptor and colorimetric chemosensor: tunable selectivity and sensitivity for anions. Org. Biomol. Chem. 2011;9:752-757;

(e) Lee GW, Kim N-K, Jeong K-S. Synthesis of biindole-diazo conjugates as a colorimetric anion receptor. Org. Lett. 2010;12:2634-2637;

(f) Nishiki M, Oi W, Ito K. Anion binding properties of indolylmethanes. J. Incl. Phenom. Macro. 2008;61:61-69;

(g) Sessler J.L., Cho D.-G., Lynch V. Diindolylquinoxalines: effective indolebased receptors for phosphate anion. J. Am. Chem. Soc. 2006;128:16518-16519;

(h) He X, Hu S, Liu K, Guo Y, Xu J, Shao S. Oxidized bis(indolyl)methane: a simple and efficient chromogenic-sensing molecule based on the proton transfer signaling mode. Org. Lett. 2006;8:333-336.

[5] Santos-Figueroa LE, Moragues ME, Climent E, Agostini A, Martínez-Máñez R, Sancenón F. Chromogenic and fluorogenic chemosensors and reagents for anions. A comprehensive review of the years 2010-2011. Chem. Soc. Rev. 2013;42:34893613.

[6] Gu R, Snick SV, Robeyns K, Meervelt LV, Dehaen W. A facile and general method for the synthesis of 6,12-diaryl-5,11-dihydroindolo[3,2-b]carbazoles. Org. Biomol. Chem. 2009;7:380-385.

[7] (a) Martinez R, Espinosa A, Tarraga A, Molina P. Bis(indolyl)methane derivatives as highly selective colourimetric and ratiometric fluorescent molecular chemosensors for $\mathrm{Cu}^{2+}$ cations. Tetrahedron 2008;64:2184-2191;

(b) Kaur P, Kaur S, Singh K, Sharma PR, Kaur T. Indole-based chemosensor for $\mathrm{Hg}^{2+}$ and $\mathrm{Cu}^{2+}$ Ions: applications in molecular switches and live cell imaging. Dalton Trans. 2011;40:10818-10821.

(c) Mahapatra AK, Hazra G, Das NK, Goswami S. A highly selective triphenylamine-based indolylmethane derivatives as colorimetric and turn-off 
fluorimetric sensor toward $\mathrm{Cu}^{2+}$ detection by deprotonation of secondary amines. Sensors Actuators Chem. 2011;156:456-462.

(d) Kaur P, Kaur $\mathrm{S}$, Singh $\mathrm{K}$. $\operatorname{Bis}(N$-methylindolyl)methane-based chemical probes for $\mathrm{Hg}^{2+}$ and $\mathrm{Cu}^{2+}$ and molecular IMPLICATION gate operating in fluorescence mode. Org. Biomol. Chem. 2012;10:1497-1501.

[8] Batista RMF, Oliveira E, Nunez C, Costa SPG, Lodeiro C, Raposo MMM. Synthesis and evaluation of new thienyl and bithienyl-bis-indolylmethanes as colorimetric sensors for anions, J. Phys. Org. Chem. 2009;22:362-366.

[9] (a) Oliveira E, Baptista RMF, Costa SPG, Raposo MMM, Lodeiro C. Exploring the emissive properties of new azacrown compounds bearing aryl, furyl, or thienyl moieties: a special case of chelation enhancement of fluorescence upon interaction with $\mathrm{Ca}^{2+}, \mathrm{Cu}^{2+}$, or $\mathrm{Ni}^{2+}$. Inorg. Chem. 2010;49;10847-10857;

(b) Pedras B, Batista RMF, Tormo L, Costa SPG, Raposo MMM, Orellana G, Capelo JL, Lodeiro C. Synthesis, characterization, photophysical studies and interaction with DNA of a new family of $\mathrm{Ru}(\mathrm{II})$ furyl- and thienyl-imidazophenanthroline polypyridyl complexes. Inorg. Chim. Acta, 2012;381:95-103.

[10] Montalti L, Credi A, Prodi T, Gandolfi MT. Handbook of Photochemistry. 3rd ed.; Taylor and Francis Group: Boca Ratón, 2006.

[11] Nagarajan R, Perumal PT. Potassium hydrogen sulfate-catalyzed reactions of indoles: a mild, expedient synthesis of bis-indolylmethanes. Chem. Lett. 2004;33:288-289.

[12] Mitsch A, Wissner P, Silber K, Haebel P, Sattler I, Klebe G, Schlitzer M. Nonthiol farnesyltransferase inhibitors: $N$-(4-tolylacetylamino-3-benzoylphenyl)-3arylfurylacrylic acid amides. Bioorg. Med. Chem. 2004;12:4585-4600.

[13] Costa SPG, Batista RMF, Cardoso P, Belsley M, Raposo MMM, 2-Arylthienylsubstituted 1,3-benzothiazoles as new nonlinear optical chromophores. Eur. J. Org. Chem. 2006;3938-3946. 


\section{Captions}

Scheme 1. Synthesis of arylfuryl-bis(indolyl)methanes 2.

Figure 1. Solid samples and $\mathrm{MeCN} / \mathrm{H}_{2} \mathrm{O}(7: 3)$ solutions $\left(10^{-4} \mathrm{M}\right)$ of compounds 2a-d.

Figure 2. Color changes of compound $2 \mathbf{b}\left(10^{-4} \mathrm{M}\right.$ in $\left.\mathrm{MeCN} / \mathrm{H}_{2} \mathrm{O}(7: 3)\right)$ in the presence of 100 equiv. of $\mathrm{Ca}^{2+}, \mathrm{Cd}^{2+}, \mathrm{Co}^{2+}, \mathrm{Cr}^{3+}, \mathrm{Cu}^{2+}, \mathrm{Fe}^{2+}, \mathrm{Fe}^{3+}, \mathrm{Hg}^{2+}, \mathrm{Pd}^{2+}, \mathrm{Ni}^{2+}$ and $\mathrm{Zn}^{2+}$ (in the form of tetrafluorborate or perchlorate salts).

Figure 3. Relative fluorimetric response $\left(I / I_{0}\right)$ of compound 2a in the presence of 100 equiv of $\mathrm{Ca}^{2+}, \mathrm{Cd}^{2+}, \mathrm{Co}^{2+}, \mathrm{Cr}^{3+}, \mathrm{Cu}^{2+}, \mathrm{Fe}^{2+}, \mathrm{Fe}^{3+}, \mathrm{Hg}^{2+}, \mathrm{Pd}^{2+}, \mathrm{Ni}^{2+}$ and $\mathrm{Zn}^{2+}$, as a function of metal concentration in acetonitrile/ $\mathrm{H}_{2} \mathrm{O}(7: 3, \mathrm{v} / \mathrm{v})$ solution.

Figure 4. Spectrophotometric titrations of $\mathbf{2 a}(\mathrm{A}), \mathbf{2 b}(\mathrm{B}), \mathbf{2 c}(\mathrm{C})$ and $\mathbf{2 d}$ (D) with addition of increasing amounts of $\mathrm{Hg}^{2+}$ in $\mathrm{MeCN} / \mathrm{H}_{2} \mathrm{O}(7: 3)$. The inset represents the normalized absorption at: 290 and $516 \mathrm{~nm}$ (A); 290 and $543 \mathrm{~nm}$ (B); 267 and $518 \mathrm{~nm}$ (C) and 377 and $505 \mathrm{~nm}(\mathrm{D})\left([\mathbf{2 a - d}]=2.5 \times 10^{-5} \mathrm{M}, \mathrm{T}=298 \mathrm{~K}\right)$.

Figure 5. Job's plot for the complexation of compounds $\mathbf{2 a - d}$ with $\mathrm{Hg}^{2+}$, indicating the formation of 1:1 complexes. The total $[2 \mathbf{a}-\mathbf{d}]+\left[\mathrm{Hg}^{2+}\right]=4.0 \times 10^{-5} \mathrm{M}$.

Figure 6. Spectrofluorimetric titrations of $\mathbf{2 a}(\mathrm{A}, \mathrm{B})$ and $\mathbf{2 b}(\mathrm{C}, \mathrm{D})$ with the addition of increasing amounts of $\mathrm{Hg}^{2+}$ in $\mathrm{MeCN} / \mathrm{H}_{2} \mathrm{O}(7: 3)$ at $\mathrm{pH} 7.0$ aqueous solution. The inset represents the normalized fluorescence intensity at $425 \mathrm{~nm}$ (A), $585 \mathrm{~nm}$ (B), $358 \mathrm{~nm}$ (C) and $625 \mathrm{~nm}(\mathrm{D})\left(\mathrm{T}=298 \mathrm{~K} ;[\mathbf{2 a}]=[\mathbf{2 b}]=2.5 \times 10^{-5} \mathrm{M}, \lambda_{\operatorname{exc}(\mathrm{A})}=290 \mathrm{~nm}, \lambda_{\operatorname{exc}(\mathrm{B})}=516 \mathrm{~nm}\right.$, $\left.\lambda_{\operatorname{exc}(\mathrm{C})}=290 \mathrm{~nm}, \lambda_{\operatorname{exc}(\mathrm{D})}=543 \mathrm{~nm}\right)$.

Figure 7. Partial ${ }^{1} \mathrm{H}$ NMR spectra of $\mathbf{2 b}\left(1.4 \times 10^{-2} \mathrm{M}\right)$ in acetone- $d_{6}$ in (a) the absence and (b) the presence of 1.0, (c) 2.0, (d) 4.0 and (e) 6.0 equiv of $\mathrm{Hg}^{2+}$. 
Table 1. Yields, IR, UV-vis absorption and emission data for arylfuryl-bis(indolyl)methanes 2a-d, in $\mathrm{MeCN} / \mathrm{H}_{2} \mathrm{O}$ (7:3) solution.

${ }^{a}$ For the NH proton (in acetone- $d_{6}$ ). ${ }^{b}$ For the NH stretching band recorded in Nujol.

Table 2. Absorption and limit of detection (LOD) and limit of quantification (LOQ) data upon titration of arylfuryl-bis-(indolyl)methanes $\mathbf{2 a - d}$ with $\mathrm{Hg}^{2+}$, in $\mathrm{MeCN} / \mathrm{H}_{2} \mathrm{O}$ (7:3) solution (L, ligand; $\mathrm{L}-\mathrm{Hg}^{2+}$, complex ligand-metal).

Table 3. Fluorescence data and limit of detection (LOD) and limit of quantification (LOQ) data upon titration of arylfuryl-bis-(indolyl)methanes $\mathbf{2 a - d}$ with $\mathrm{Hg}^{2+}$, in $\mathrm{MeCN} / \mathrm{H}_{2} \mathrm{O}$ (7:3) solution (L, ligand; $\mathrm{L}-\mathrm{Hg}^{2+}$, complex ligand-metal). 


\section{Figures}

Figure 1.

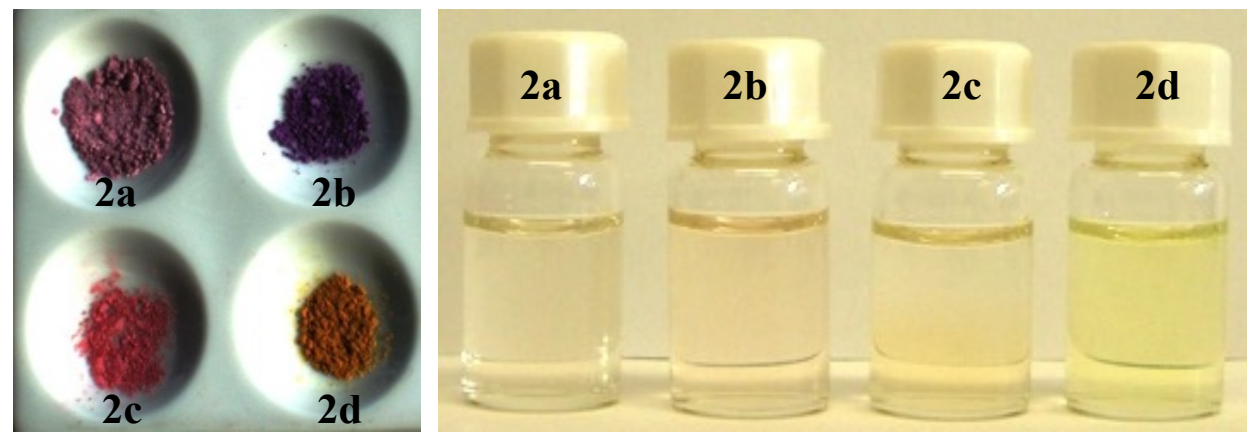

Figure 2.

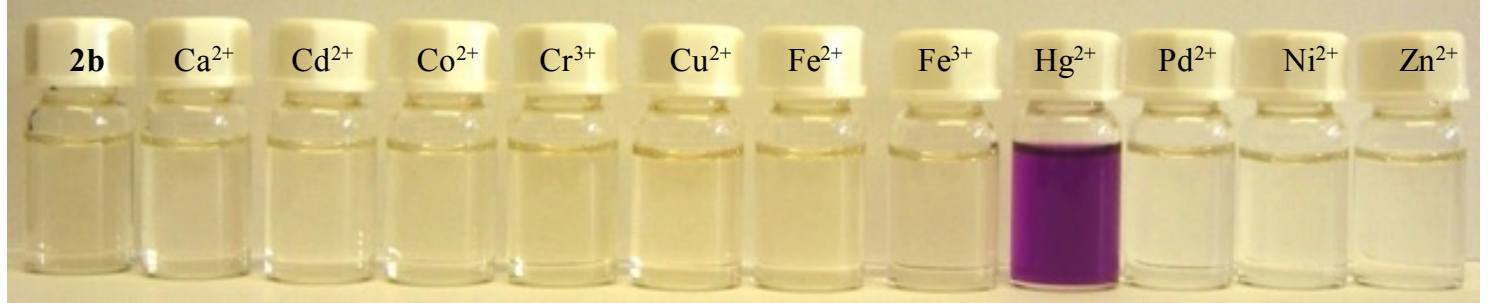

Figure 3.

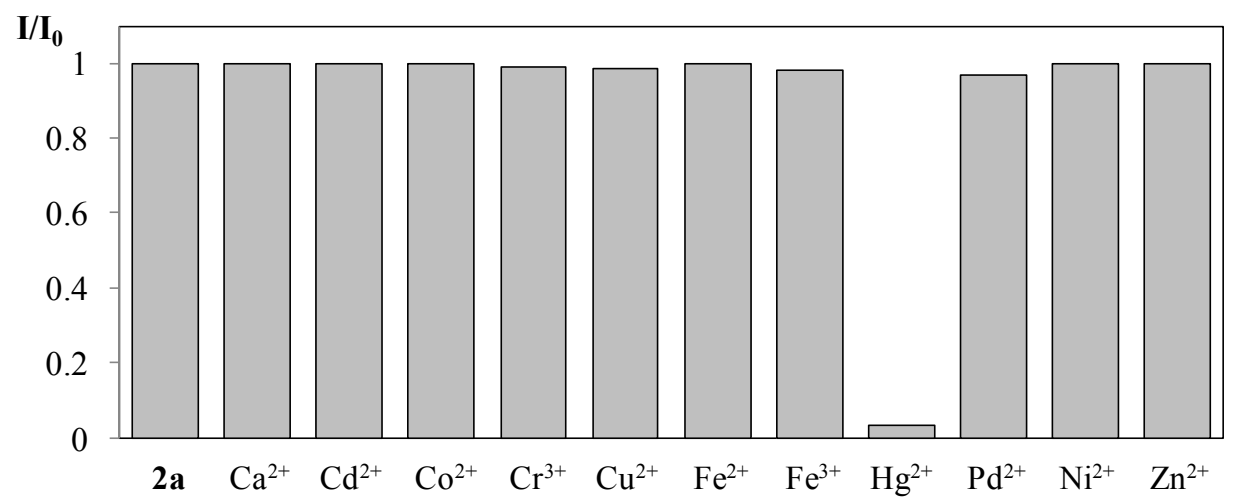


Figure 4.
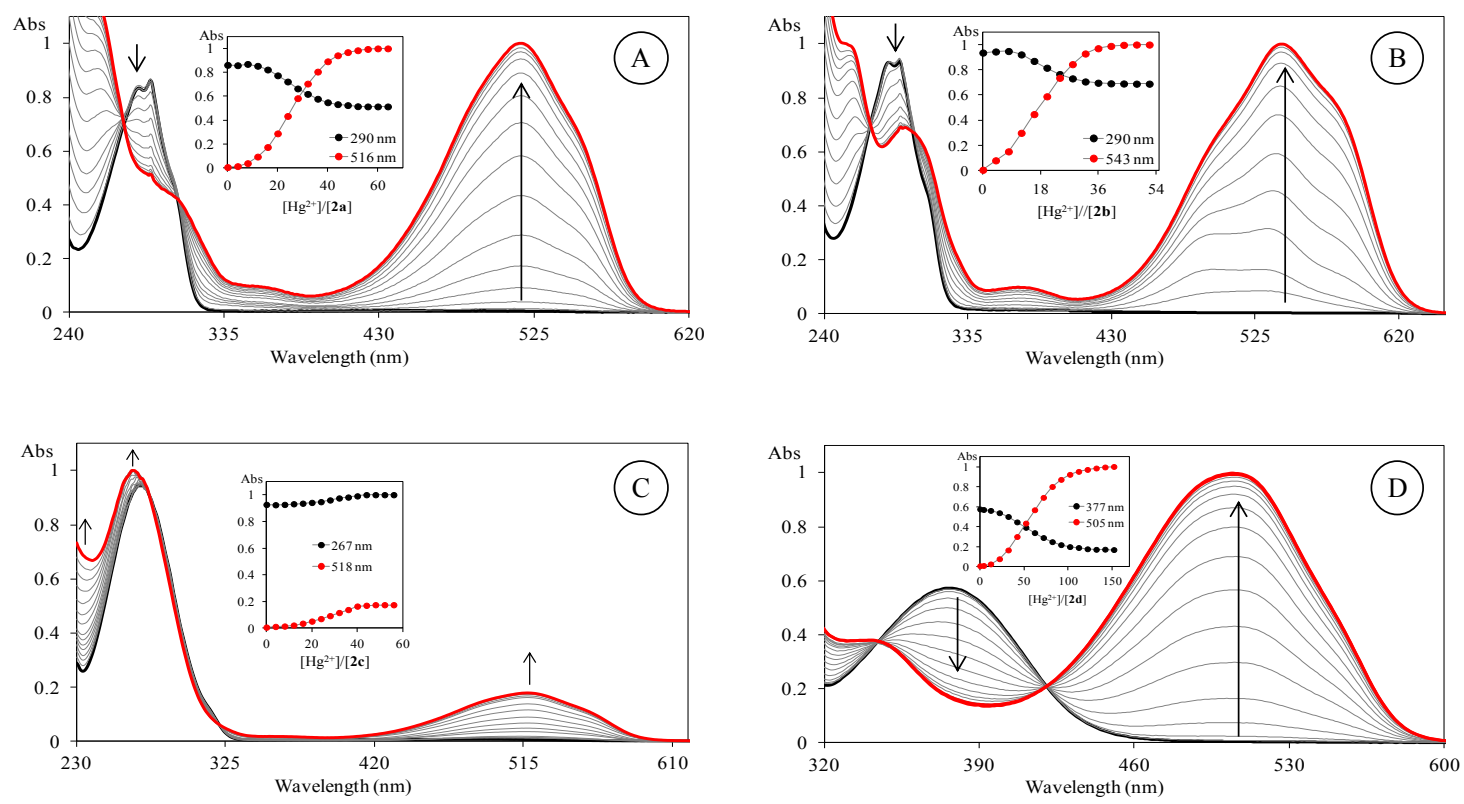

Figure 5.
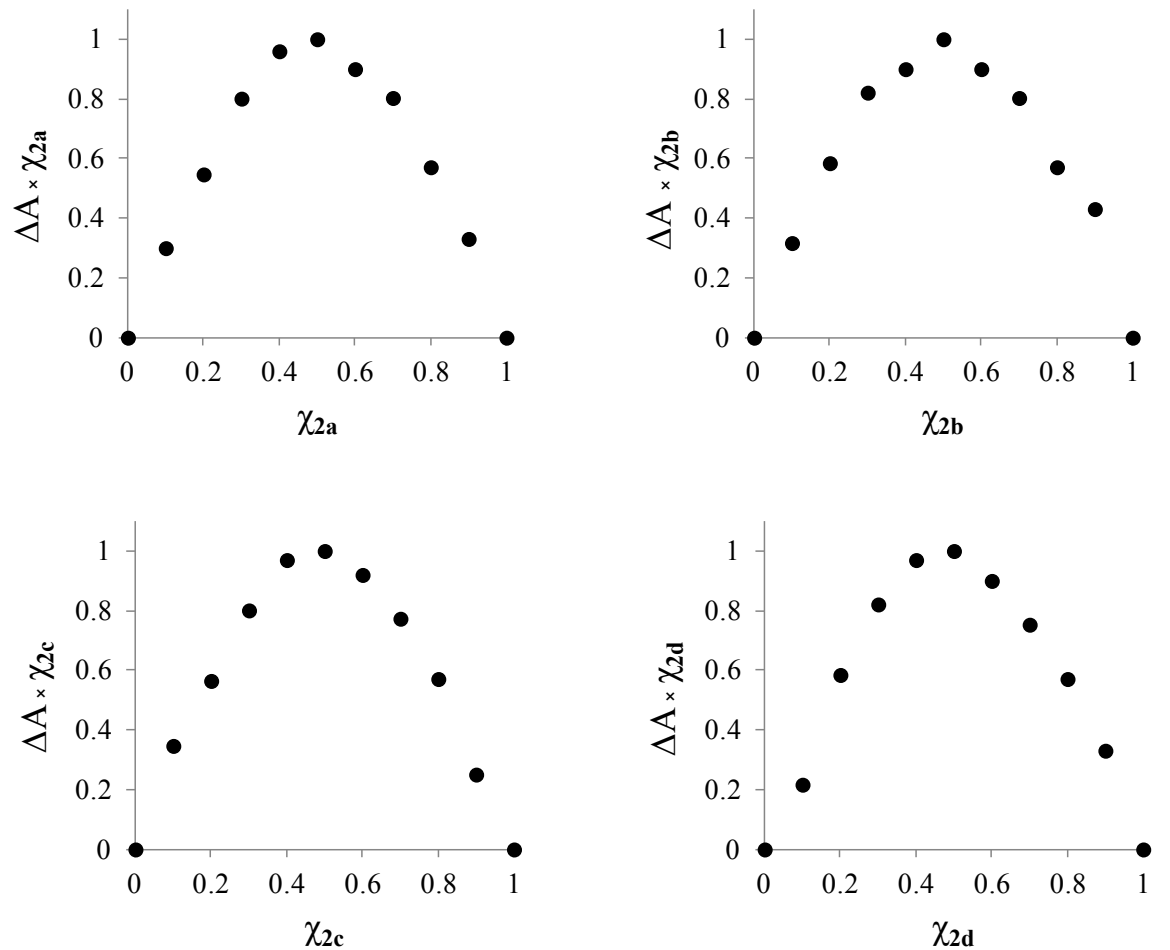
Figure 6.
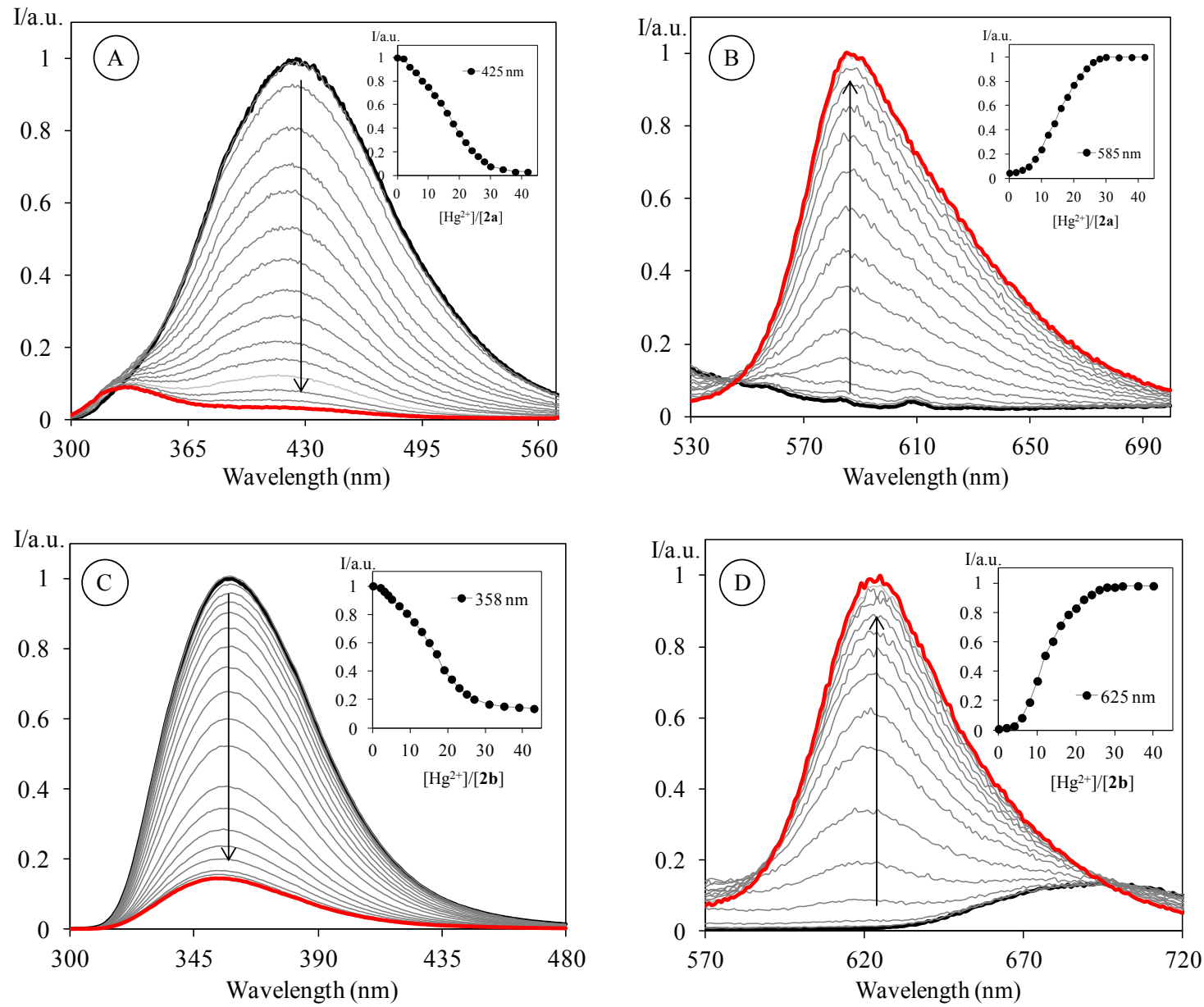
Figure 7.

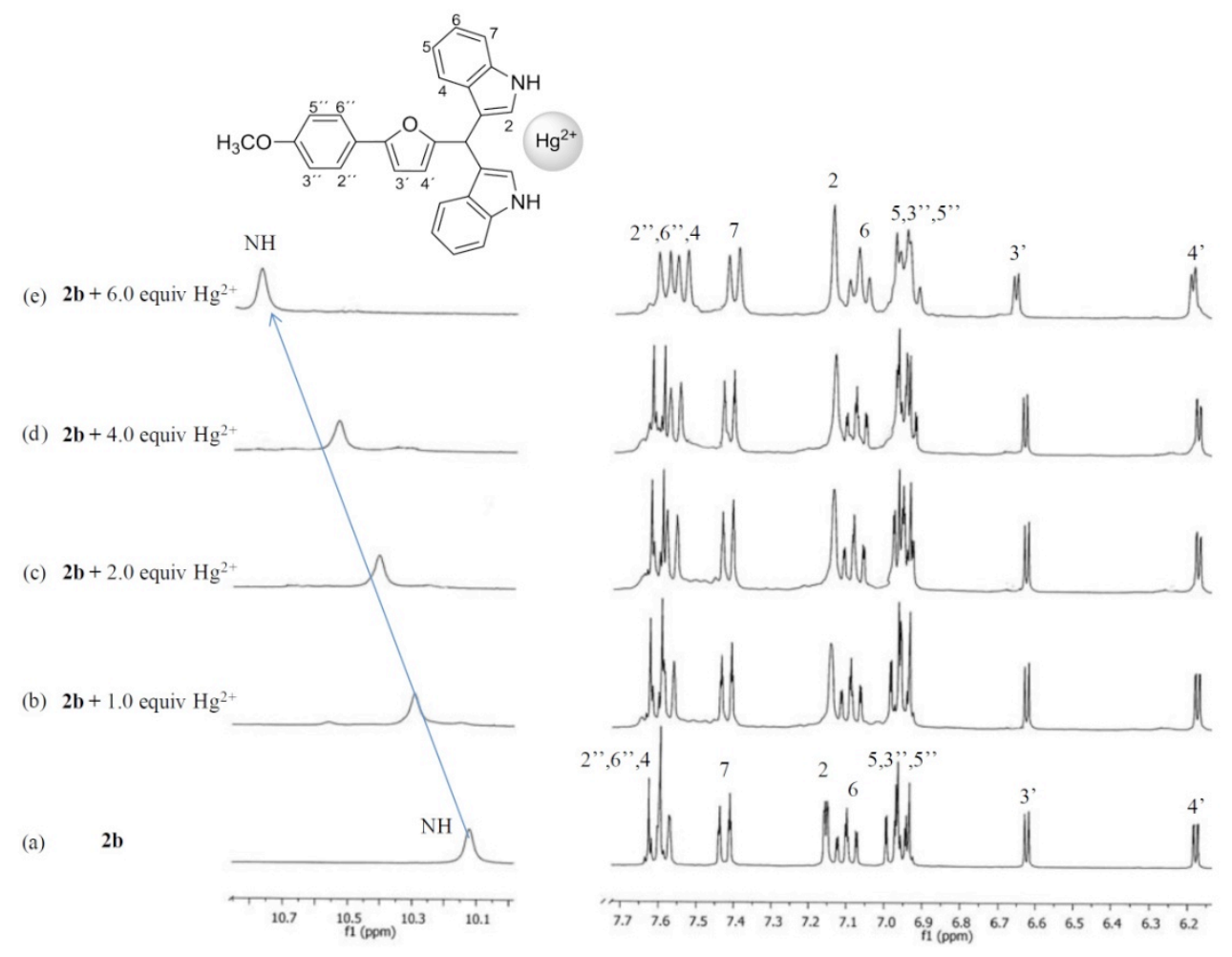


Tables

Table 1

\begin{tabular}{ccccccccc}
\hline & & & & & UV-vis & \multicolumn{3}{c}{ Fluorescence } \\
\cline { 6 - 9 } Cpd & $\mathrm{R}$ & Yield & $\delta_{\mathrm{H}}$ & IR $v$ & $\lambda_{\text {abs }}(\mathrm{nm})$ & $\begin{array}{c}\lambda_{\mathrm{em}} \\
(\mathrm{nm})\end{array}$ & $\begin{array}{c}\text { Stokes'shift } \\
\left(\mathrm{cm}^{-1}\right)\end{array}$ & $\mathrm{F}$ \\
\hline 2a & $\mathrm{H}$ & 50 & 10.11 & 3412 & 288 & 425 & 10953 & 0.21 \\
2b & $\mathrm{OMe}$ & 40 & 10.10 & 3411 & 289 & 358 & 6549 & 0.58 \\
2c & $\mathrm{Br}$ & 54 & 10.10 & 3409 & 287 & 387 & 11613 & 0.01 \\
2d & $\mathrm{NO}_{2}$ & 65 & 10.15 & 3409 & 370 & 412 & 2755 & 0.001 \\
\hline
\end{tabular}

Table 2

\begin{tabular}{|c|c|c|c|c|c|c|}
\hline \multirow[b]{2}{*}{ Cpd. } & \multicolumn{2}{|c|}{ UV-vis } & \multirow[b]{2}{*}{$\begin{array}{c}\text { Isosbestic points } \\
\text { (nm) }\end{array}$} & \multirow[b]{2}{*}{$\log K_{\text {ass }}$} & \multirow[b]{2}{*}{$\begin{array}{l}\text { LOD } \\
(\mathrm{ppm})\end{array}$} & \multirow[b]{2}{*}{$\begin{array}{l}\text { LOQ } \\
(\mathrm{ppm})\end{array}$} \\
\hline & $\begin{array}{l}\mathrm{L} \\
\lambda_{\mathrm{abs}}(\mathrm{nm})\end{array}$ & $\begin{array}{l}{\mathrm{L}-\mathrm{Hg}^{2+}} \\
\lambda_{\text {abs }}(\mathrm{nm})\end{array}$ & & & & \\
\hline $2 a$ & 290 & 516 & 274,307 & $2.01 \pm 0.03$ & 20.2 & 67.5 \\
\hline $2 b$ & 290 & 543 & 271,299 & $2.90 \pm 0.01$ & 10.6 & 35.6 \\
\hline $2 c$ & 270 & 518 & --- & $1.90 \pm 0.03$ & 24.7 & 82.2 \\
\hline 2d & 377 & 505 & 344,420 & $1.76 \pm 0.02$ & 31.7 & 105.7 \\
\hline
\end{tabular}

Table 3

\begin{tabular}{cccccccc}
\hline & \multicolumn{9}{c}{ Fluorescence } & & & \\
Cpd & $\mathrm{L}$ & Stokes & ${\mathrm{L}-\mathrm{Hg}^{2+}}^{2+}$ & Stokes & Log $K_{\text {ass }}$ & LOD & LOQ \\
& $\begin{array}{c}\lambda_{\text {emis }}(\mathrm{nm}) \\
\text { shift }\left(\mathrm{cm}^{-1}\right)\end{array}$ & $\begin{array}{c}\lambda_{\text {emis }}(\mathrm{nm}) \\
\text { shift }\left(\mathrm{cm}^{-1}\right)\end{array}$ & & $(\mathrm{ppm})$ & $(\mathrm{ppm})$ \\
\hline $\mathbf{2 a}$ & 425 & 10953 & 585 & 2285 & $3.801 \pm 0.003$ & 8.5 & 28.3 \\
$\mathbf{2 b}$ & 358 & 6549 & 625 & 2416 & $3.691 \pm 0.005$ & 10.8 & 36.1 \\
\hline
\end{tabular}




\section{Schemes}

Scheme 1.

(

1a $\mathrm{R}=\mathrm{H}$

1b $\mathrm{R}=\mathrm{OMe}$

1c $\mathrm{R}=\mathrm{Br}$

1d $\mathrm{R}=\mathrm{NO}_{2}$

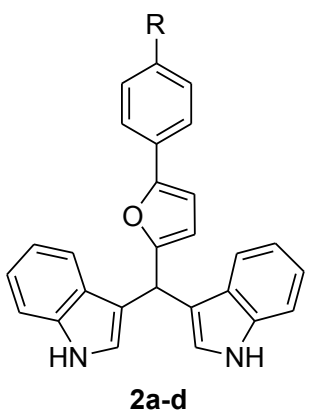

